\title{
Gender Justice and Food Security: The case of public distribution system in India
}

Mamata Pradhan and Nitya Rao

\section{Abstract:}

This paper contributes to the debates around food and nutrition security from a perspective of gender justice, central to which is the recognition of men and women as having equal rights and entitlements to a life free from hunger and malnutrition. Using both quantitative and qualitative data from the Indian state of Bihar, we assess various elements of gender justice through the functioning of the Public Distribution System, the largest food based safety net programme in the world. Despite universal entitlements, we find that power relations embedded in local politics, caste and class heterogeneity and political economy considerations, mediate the gendered access to food through state transfers.

\section{Keywords}

Gender justice, food and nutrition security, India, Public Distribution 


\section{Introduction}

Despite sustained economic growth over the last decade, a sixth of India's population and a fifth of its children remain undernourished (IFPRI, 2017). Since 2000, global attention has been focused on food security and nutrition, first through the Millennium Development Goals (MDGs), and now through Goal 2 of the Sustainable Development Agenda. Indian policy-makers recognise freedom from hunger as a basic human right, and acknowledge the significant role of women in ensuring household food security. The National Food Security Act (NFSA) 2013 formalises this recognition by legitimising the senior most woman in the household as its 'head' for securing food entitlements. ${ }^{1}$ This is indeed a welcome step, but it also brings forth the need to better understand the linkages between the recognition of women in food security policies, gender relations on the ground, and outcomes related to food and nutrition security.

In this paper, we first set out the multi-dimensional nature of food security and nutrition from the perspective of gender justice. Invoking of gender justice brings to attention the gender power dynamics across a range of areas from resource access and control to the feminization of agriculture, women's unpaid domestic and care work, wage gaps, and the nature of social protection and rights legislation. These vary across caste and ethnicity, class and religion, as women, and for that matter men, are not a homogenous group, rather they are embedded in a web of complex social relations. Among the poorest and asset less, gender relations are often more equitable and resources shared, as unless both spouses cooperate, survival itself may be threatened (Swaminathan et al. 2011). Yet, women in these groups, lacking in assets and social networks, are often excluded from state entitlements (Author 2008), including institutional credit (Prakash, 2010) and public extension services (Birner and Anderson, 2007). We focus here on one element i.e. food based social safety net

\footnotetext{
${ }^{1}$ http://dfpd.nic.in/Salient-features-National-Food-Security-Act.htm
} 
programmes, to explore these dynamics. We analyse the Public Distribution System (PDS), the largest food subsidy programme in the world.

In section 1, we conceptualise our understanding of gender justice in relation to food security. Section 2 sets out the data used and context of the study, Section 3 analyses key elements of gender power dynamics in relation to one of the three pillars of food security, namely, the economic and social access to food. ${ }^{2}$ In section 4 , we provide some conclusions and possible implications for research and policy.

\section{Section 1: Framing the debate}

\subsection{What does gender justice in food security policies mean?}

The commitment to food and nutrition security adopted at the World Food Summit (FAO, 1996), articulates the need for gender equality and women's empowerment, in line with the Beijing Platform for Action, 1995. It supports the equal participation of men and women by ensuring equal access to productive assets (land, water, credit), technologies and services. Nevertheless, it falls short of the goals of gender justice, by ignoring the reality of unequal gender relations, divisions of labour, and social normative expectations, across societies.

An alternate conceptualisation of 'gender-just' food and nutrition security would not only mean "a world without hunger, where women, men, girls and boys have equal access to nutritious, healthy food" (BRIDGE 2015), but equally have access to the means to produce, sell and purchase food. There is a larger dimension of gender justice as well, which includes "a world free of gender-based violence, where the roles, responsibilities, opportunities and choices available to women and men including unpaid caregiving and food provision - are not predetermined at birth but

\footnotetext{
${ }^{2}$ The other two pillars are food availability (through adequate food production), and utilization and stability (nutrition security) (FAO, 1996).
} 
can, where possible, be developed in line with individual capacities and aspirations" (Ibid.).

There are three elements to this larger vision of gender justice. First, the concept of 'justice' implies an entitlement backed by law, a right rather than a welfare support to 'beneficiaries' at the State's discretion. Entitlements are based on alternate ideologies and justifications of what is fair in terms of resource allocation - should it be the "pursuit of human fulfilment, or removal of poverty, or entitlement to enjoy the products of one's own labour" (Sen, 2009:14). Each of these justifications would point to a different social arrangement, enabled through different incentives and social institutions.

In India, over the past decade, in response to grassroots mobilisation and advocacy, the state has increasingly moved away from a welfarist (needs-based) approach, which involved large exclusion and inclusion biases (Deaton and Dreze, 2002), to creating a rights-based framework for entitlements. This is important for ensuring the dignity of human beings, their right to live a healthy and fulfilling life, as deprivation is often a result of discrimination across generations, rather than an individual flaw (Thorat and Sadana 2009). In this sense, the National Food Security Act (NFSA), 2013, at least in ideological terms, replaces relations of patronage with a legitimate claim or right of citizens.

Food constitutes the basic element for a functioning life, hence access to food cannot and should not be mediated through social hierarchies and identities. Yet as Ribot and Peluso (2003: 153) note, the idea of access as "the ability to derive benefits from things," broadening from the classical definition as "the right to benefit from things", suggests that access is more akin to "a bundle of powers" than to property's notion of a "bundle of rights". This formulation, the authors maintain, consists of a 
wider range of social relationships (like gender, caste, class, local power) that constrain or enable benefits from resource use.

Second, the perspective of gender justice recognises that gender-based violence is a tool of control within patriarchy, and a mechanism for wider social control, including of the poor, lower castes and tribes in the case of India. While food deprivation itself can be considered a form of violence, hunger and food insecurity can also aggravate other forms of violence, including early marriage, trafficking of young girls and intimate partner violence, especially in times of crisis. Unpacking the gendered nature of decision-making and resource allocation at various levels, to reveal the trade-offs between short-term wellbeing and investments in future security, could indicate the nature and scale of injustices that need to be challenged in order to transform relations of dependence that perpetuate such violence.

Third, the problem of food insecurity is multi-dimensional and interconnected; it involves food but equally broader visions of wellbeing and freedoms (Sen 1999). The persistent discrimination of the poor, Scheduled castes and tribes in India, and women within these groups, often leads to their engagement with forms of work that are low-paid, insecure and risky, for the sake of survival, rather than an enhanced sense of choice or wellbeing (Author, 2014). Interestingly, 2005 was a watershed year with the passage of the Mahatma Gandhi National Rural Employment Guarantee Act (MGNREGA), which transformed decent work into a right. The same year witnessed an amendment to the Hindu Succession Act, 1956, providing daughters equal rights to inherit property as sons, and the Prevention of Domestic Violence Act, to protect women from domestic abuse - both central to ensuring gender justice. Just as the lack of assets, land, in a rural context, can enhance women's vulnerability, gender based violence can undermine women's rights, impeding access to the public sphere and in turn access to food. Unequal 
power relations based on gender or social identity, here dictate unequal relations to resources, claims and responsibilities (Kabeer, 1994).

Though a significant strand of literature analyses the links between gender justice and food and nutrition security by exploring the domain of production, namely, addressing the 'resource gaps' women confront in agriculture (FAO, 2011), we focus on the access to food through state transfers, here the Indian Public Distribution System (PDS). From a gender justice perspective, we examine issues of access, entitlement and the quality of service delivery for differently positioned women. We focus on rural areas in the state of Bihar (East India), one of the poorest in the country.

\subsection{Food Entitlements and The Public Distribution System in India}

Given the burden of hunger and malnutrition, the Public Distribution System (PDS) for food can play a key role in ensuring access to food for the poor and in mitigating the impact of shocks, both natural (drought, flood) and market-based (price fluctuations, shortages). PDS is one of the most extensive social safety net programmes in the world, distributing food grains to about 160 million people every year using 400,000 Fair Price Shops (FPS) (Dreze and Khera 2013). In Bihar, PDS currently provides two main cereals viz. rice and wheat and supplies sugar. While plagued with significant leakages and corruption in the past, the PDS in Bihar appears to have turned a corner with leakages plummeting from over 70 percent to only 24 percent currently (Dreze and Khera 2013). The drivers for this turnaround remain to be rigorously researched and established.

Entitlements to food can be accessed through production, market exchange, or state provisioning (Sen, 1981). In focusing on state transfers in this paper, two issues need consideration: the quality of rights and the mechanisms for their enforcement. As per the NFSA (2013), nearly two thirds of the population - 75 per cent rural and 50 per 
cent urban - are entitled to food grains at subsidised rates. Each household is provided a ration card, and depending on their economic status, the price of the grain is fixed. While before the NFSA, households were classified into three categories, namely, Above Poverty Line (APL), Below Poverty Line (BPL) and poorest of the poor-Antodaya Anna Yojana (AAY), there are now two main categories of entitlement-holders: Antodaya Anna Yojana (AAY) households or the poorest of the poor; and Priority Households (PHH), who hold BPL (Below Poverty Line) or NFS cards. Foodgrains entitlement are $5 \mathrm{~kg}$ per person for PHH category and $35 \mathrm{~kg}$ per household for AAY households; prices are fixed at INR 3/2/1 per kg for rice, wheat and coarse grains respectively.

Since the implementation was not fully completed in Bihar at the time of data collection, not all households had cards under NFSA; some still possess the earlier BPL and APL cards. To ease the implementation challenges, the PDS shops are directed to accept any type of ration card. In our sample (Table 2) nearly $98.6 \%$ are ration card holders (ration card is a union of any of the sub types of card), of which 47.3\% are BPL card holders, AAY card holders account for nearly $15 \%$, while $35 \%$ are NFS card holders (PHH).

While a universal entitlement, the workings of social and economic hierarchies based on gender, caste and class are visible on both the supply and demand sides (Deshpande, 2002). If women, particularly from the lower castes, confront discrimination, they may decide to self-select out of the PDS to maintain their dignity. Alternatively, in the absence of commensurate policy and institutional responses, and grievance redressal systems, there could be an informal screening, with some households, comprising women, who are economically and politically less powerful, denied access. 
Even without selection or screening, social identity as reflected in the intersections of gender, caste and class, could bear on the intensity of engagement with the PDS as well as the quality of services rendered. Quality of services comprise entitlement snatching (less quantities provided than entitled) or price magnification (charging of prices higher than government mandated). Even if the prices charged and the quantities disbursed were adequate, there are ways in which some groups could receive suboptimal services from the PDS, in terms of the quality of grains or the general service experience of waiting time, harassment or just lack of treatment with dignity (Grace Carswell personal communication). Thorat and Lee (2006) note that women, especially of the lower castes are often prohibited from participation, if not actively discriminated against. In their five village study, they cite four forms of "discriminatory practices" against the Dalits (lower caste) - "discrimination in quantity, discrimination in price, caste-based favouritism by the PDS dealer, and practices of "untouchability" by the PDS dealer" (Ibid: 4200).

Fair Price Shops (FPS) are the last node of delivery and most outcomes are a function of the interactions between women entitlement-holders and the PDS dealer. ${ }^{3}$ These relations are mediated through the social identity of the claimant, the social networks and power structures within the village community, the leadership and functioning of the local government (panchayats), and the responsibilities of state functionaries. The precedence of informal rules at this stage reproduce the existing, unequal social and economic power structures, affecting fair allocation of benefits through the PDS, and in turn compromising citizen rights and entitlements.

The PDS is visualised as a tool for improving the wellbeing of the poor and vulnerable in multiple ways. Apart from ensuring minimum food (calories) to all

\footnotetext{
3 "Fair price shop" means a shop which has been licensed to distribute essential commodities by an order issued under section 3 of the Essential Commodities Act, 1955, to the ration card holders under the Public Distribution System. (National Food Security Act (2013, Chapter 1)
} 
citizens, it bears on the multiplicity of tasks performed primarily by women within households, such as having to go to distant markets to buy food, alongside food processing and preparation. At the same time, poor delivery could threaten wellbeing. For example, low quality grains would imply adding to women's work burdens (clean, sort and cook the often substandard PDS rice), and care tasks (looking after sick children), a very important element of gender justice. While the social construct of gender, and its interactions with caste and class, shape women's bargaining power within the household and beyond, in the interlinked institutional arenas of the market, the community and the state (Agarwal, 1997, Kabeer, 1994), we try to highlight the contradictions and injustices that need to be overcome in accessing entitlements. We seek to capture this complexity of relationships through a focus on labour time and social interactions in relation to the PDS.

\section{Section 2: Data and Context}

The data for this study has been collected from extensive field-work in Bihar, involving both quantitative as well as qualitative methods, between February to June 2016. Bihar offers significant variation in the functioning of the PDS and contrasting experiences across districts, and villages (Table 1). The quantitative data was collected through a structured questionnaire in 32 villages across five districts Patna, Darbhanga, Banka, Munger and West Champaran, with information on socioeconomic and demographic characteristics, and current and prospective engagement with the PDS. The survey also provides information on the purchases of rice and wheat and issues of access to the PDS. The qualitative data used in this paper was collected through interviews and observations in three villages in Patna district. The respondents were household members who had experience of the PDS, and were generally women, especially as Patna district has a high incidence of male migration. 


\begin{tabular}{|c|c|c|c|c|c|}
\hline & $\begin{array}{c}\text { Population } \\
\text { Density (Sq Km) }\end{array}$ & $\begin{array}{c}\text { Urban } \\
\text { Population }\end{array}$ & $\begin{array}{c}\text { Rural } \\
\text { Population }\end{array}$ & Literacy & $\begin{array}{c}\text { Sex } \\
\text { Ratio }\end{array}$ \\
\hline Patna & 1800 & 43.7 & 56.3 & 73.68 & 897 \\
\hline Darbhanga & 1700 & 8.7 & 91.3 & 58.26 & 910 \\
\hline Banka & 670 & 3.51 & 96.49 & 60.12 & 907 \\
\hline Munger & 960 & 16.59 & 83.41 & 73.3 & 879 \\
\hline West Champaran & 750 & 10.09 & 89.91 & 58.06 & 906 \\
\hline
\end{tabular}

Source: NSSO data

The average size of landholding ranges from 0.31 hectare in Darbhanga to 0.45 in Banka. Though agriculture and livestock-rearing constitute the main economic activity in the region, many households seek employment in the non-farm sector. The houses in these villages are a combination of both pucca (solid and permanent) and semi-pucca houses. The social structure is highly patriarchal and maledominated as revealed by the low sex ratios.

\subsection{Sample Composition:}

Table 2 presents the sample composition in terms of socio-economic characteristics. There are five main social groups in the field site: Scheduled Caste (SC), Scheduled Tribes (ST), Other Backward Classes (OBC), Minorities and Upper/General Caste. These are administrative categories; social identity on the ground is defined more at the sub caste or clan level. OBCs at 55 percent formed the majority, and included groups such as the Yadavs and Mauryas. They were followed by the SCs (Chamars, Mochi, Dhobi, Dusadh) at 20 per cent, STs at 12 per cent and general or upper castes (including the land-owning Bhumihars, Rajputs, Brahmins) forming 11 percent. In this paper, we mainly focus on the relationship between the Bhumihars, Yadavs and SCs.

Table 2: Sample Composition

\begin{tabular}{|l|l|}
\hline Bihar & 962 \\
\hline Sample Size & 48.26 \\
\hline Age of the respondent & 6.12 \\
\hline Household size & 29.52 \\
\hline Female (\%) &
\end{tabular}




\begin{tabular}{|l|l|}
\hline \multicolumn{2}{|l|}{ Percentage of respondent belonging to } \\
\hline Scheduled caste & 19.85 \\
\hline Scheduled tribe & 12.16 \\
\hline Other Backward caste & 55.41 \\
\hline Minorities & 1.87 \\
\hline Upper caste/upper caste & 10.71 \\
\hline Percentage of respondents who & 53.06 \\
\hline No School & 17.72 \\
\hline Primary School & 12.97 \\
\hline Middle School & 10.13 \\
\hline High School & 3.16 \\
\hline Intermediate & 2.96 \\
\hline Bachelors and above & \multicolumn{2}{|l|}{} \\
\hline Percentage of respondents who & \\
\hline Have migrants (\%) & 27.01 \\
\hline BPL Card holder (\%) & 47.3 \\
\hline AAY Card holder (\%) & 14.66 \\
\hline NFS Card holder (PHH) \% & 35.24 \\
\hline Ration Card Holder (\%) & 98.69 \\
\hline FPS availability in their village (\%) & 72.74 \\
\hline Aadhar Card holder (\%) & 74.69 \\
\hline Bank Account (\%) & 78.88 \\
\hline Aadhr is 12-digt unque idetifction
\end{tabular}

Aadhar is a 12-digit unique identification number issued by the Indian government to every resident of India.

Family size and structure has a direct relationship with food entitlements as household allocations (for households other than the poorest of the poor (AAY)) are defined in per capita terms. The average family size therefore shapes the entitlement as well as engagement with the PDS. Extensive male migration has further led to almost 35 percent households becoming de facto female-headed (FHHs). They often face covert forms of discrimination when accessing the PDS as discussed next.

Within the sample, there are significant differences based on caste, gender, economic standing and political connectedness. Land is an important source of economic and political power for rural households. Nearly 52 per cent of households' primary source of income is wage labour. This heterogeneity is important where landlessness or small landholdings result in a greater stake in the PDS. In this context, the inheritance laws that de facto restrict land ownership for women deny them an 
important source of local power, reflected in lower levels of access, and indeed bargaining power.

\subsection{Eligibility for services}

With significant heterogeneity in effective dependence on the PDS, the question arises who can avail of the benefits, particularly with attributes that can be considered gender just. One of the most basic determinants of access is possession of a ration card, i.e. entitlement to food subsidy. Households may not possess a ration card because of different socio-political-economic factors. This was evident from the case of a 75-year-old SC woman. Since her late husband was against the upper caste Mukhiya (village headman), she was denied all benefits - the ration card and pension included.

The ward members and the Mukhiya himself admitted that they had purposefully cut off her name from the beneficiary list since her late husband was against their faction. The ability to deny or delay cards that protect entitlements, plays a key role in local power relations and can affect women negatively in the given patriarchal social context. They end up waiting, queueing and begging, constructed as dependent clients of the welfare state, rather than rights-bearing citizens (Fraser, 1989, Carswell, 2018. personal comm.), their labour time devalued and dignity compromised in the process. Those with money, social networks and political connections can speed up the process of gaining cards and securing their entitlements (Ibid.). Deshpande (2007), in constructing a Gender-Caste Development Index (GCDI), which quantifies intergroup disparity based on gender and caste, shows that for all Indian states, women in the OBC category are the best off, while SC-ST women are the worst off. The intersectionality emerges quite vividly in the qualitative data. 
With the survey finding that over 98 per cent of households having some type of ration card, including FHHs, the above example of denial seems to be an exception. Outright denial has now been replaced by more subtle methods of discrimination relating to the type of card, the quality of services and the very nature of social interaction as discussed in the next section.

\section{Section 3: Markers of access: Insights from the Survey}

As noted in section 1.2, we examine access from the perspective of quality of services rendered, specifically in terms of entitlement snatching versus entitlement fetching and price magnification. For the statistical analysis, we create a metric that measures the wedge between per capita entitlement and the actual amount received. If the quantity received is lower than the entitlement, this would be tantamount to entitlement snatching. Effective price is the price paid weighted by the entitlement to accrual ration (details in appendix 1). We are particularly interested in the likelihood of $\mathrm{FHH}$ having greater incidence of snatching or price magnification. Other things being equal, do FHH get lower quantity of grains relative to their entitlements?

With cross-sectional data, we use a rich set of controls to minimize omitted variable bias. Several factors prevalent at the level of village have a relationship with snatching and price magnification. We thus control for village level factors by adding village dummies to the regressions. Table 3 presents the results for rice and wheat. In this analysis, it is important to control for varying entitlements, hence we include the nature of card held i.e. AAY card or PHH/NFSA card.

The regressions interestingly reveal no significant difference in the quantity snatched based on gender. If anything, there is less snatching from $\mathrm{FHH}$ after controlling for other factors. The same is the case for the other measure of identity, that is, caste. The coefficients on the interactions between caste and gender are all insignificant, 
pointing to no evidence of intersectionality. Yet what the qualitative data reveals is that the quantity of grains or level of prices are not necessarily the levers of discrimination across different identities; these are easier to spot and oppose. With low prices under NFSA, a one rupee or higher price is easily accepted unopposed. Rather there are sources of compromised access reflected in the quality of the grains disbursed to diverse types of households as well as the quality of services provided during delivery. Hence, while FHH do not seem to be disadvantaged in terms of quantity and price, there are less explicit sources of discrimination at play.

Almost all the respondents complained about the inferior quality of rice provided. The elements of inferior quality included bad odour, bad taste, bad colour, mixing with stones and other elements, at times insects are also found in the grains. Some noted that the allotted rice is inedible and that they are forced to ultimately buy from the market. However, the major complaint by most of the women was that the dealer blended good and inferior quality rice together, despite their requests to give them separately. Back home women must work to sort and separate the grains, along with other household chores and care of children. This has led to women experiencing additional demands on their time, though this too varies by caste and class. We return to this in greater depth in the next section.

Table 3: Entitlement snatching and effective prices

\begin{tabular}{|c|c|c|c|c|}
\hline VARIABLES & $\begin{array}{c}\text { Capita_Differ_Rice_PDS } \\
\text { Quanti }\end{array}$ & $\underset{i}{\text { Capita_Differ_Wheat_PDS_Quant }}$ & $\begin{array}{l}\text { Effective } \\
\text { pricerice }\end{array}$ & $\begin{array}{l}\text { Effective } \\
\text { price } \\
\text { wheat }\end{array}$ \\
\hline \multirow[t]{2}{*}{ Age } & -0.00155 & 0.00321 & 0.00401 & 0.00151 \\
\hline & $(0.0113)$ & $(0.0111)$ & $\begin{array}{c}(0.00260 \\
)\end{array}$ & $\begin{array}{c}(0.00139 \\
)\end{array}$ \\
\hline \multirow[t]{2}{*}{ illiterate } & 0.332 & 0.244 & -0.0571 & -0.0544 \\
\hline & $(0.295)$ & $(0.290)$ & $(0.0706)$ & $(0.0374)$ \\
\hline \multirow[t]{2}{*}{$\mathrm{FHH}$} & $-0.587^{\star}$ & $-0.578^{\star}$ & 0.0639 & $0.0650^{\star}$ \\
\hline & $(0.300)$ & $(0.296)$ & $(0.0717)$ & $(0.0382)$ \\
\hline $\begin{array}{l}\text { Number of } \\
\text { months rice }\end{array}$ & -0.0928 & $0.233^{\star}$ & 0.0284 & -0.0264 \\
\hline
\end{tabular}




\begin{tabular}{|c|c|c|c|c|}
\hline got & $(0.140)$ & $(0.138)$ & $(0.0437)$ & $(0.0237)$ \\
\hline \multirow{2}{*}{$\begin{array}{r}\text { Number of } \\
\text { months } \\
\text { wheat got }\end{array}$} & 0.0254 & -0.160 & 0.0235 & 0.0242 \\
\hline & (0.125) & $(0.123)$ & $(0.0349)$ & $(0.0214)$ \\
\hline \multirow{2}{*}{$\begin{array}{r}\text { Whether } \\
\text { FPS within } \\
\text { village }\end{array}$} & -0.160 & -0.418 & 0.00293 & -0.00703 \\
\hline & (0.628) & $(0.618)$ & (0.152) & $(0.0805)$ \\
\hline \multirow{2}{*}{$\begin{array}{l}\text { Whether } \\
\text { FPS has } \\
\text { electronic } \\
\text { weighing }\end{array}$} & -0.143 & -0.0333 & -0.0538 & 0.0510 \\
\hline & $(0.447)$ & $(0.440)$ & $(0.121)$ & $(0.0657)$ \\
\hline \multirow{2}{*}{$\begin{array}{r}\text { Scheduled } \\
\text { caste }\end{array}$} & -0.343 & -0.0876 & $-0.265^{\star}$ & $-0.154^{\star \star}$ \\
\hline & $(0.765)$ & $(0.753)$ & $(0.147)$ & $(0.0776)$ \\
\hline \multirow{2}{*}{$\begin{array}{r}\text { Scheduled } \\
\text { tribe }\end{array}$} & -0.137 & 0.0925 & -0.275 & -0.140 \\
\hline & (1.003) & $(0.987)$ & $(0.227)$ & (0.122) \\
\hline \multirow{2}{*}{$\begin{array}{r}\text { Other } \\
\text { backward } \\
\text { caste }\end{array}$} & -0.241 & -0.0894 & $-0.352^{\star \star \star *}$ & $-0.190^{\star \star *}$ \\
\hline & $(0.716)$ & $(0.704)$ & (0.130) & $(0.0685)$ \\
\hline \multirow{2}{*}{$\begin{array}{r}\text { Minority } \\
\text { status }\end{array}$} & -0.496 & -0.576 & -0.325 & -0.0900 \\
\hline & $(1.313)$ & (1.292) & (0.295) & $(0.155)$ \\
\hline \multirow{4}{*}{$\begin{array}{l}\text { Dummy for } \\
\text { beneficiary } \\
\text { knowledge } \\
\text { on quantity } \\
\text { entitlement }\end{array}$} & -0.00700 & -0.177 & $-0.154^{\star \star}$ & $-0.0749^{\star}$ \\
\hline & & & & \\
\hline & & & & \\
\hline & (0.332) & $(0.327)$ & $(0.0785)$ & $(0.0416)$ \\
\hline \multirow{2}{*}{$\begin{array}{r}\text { Knows about } \\
\text { mandated } \\
\text { price }\end{array}$} & -0.567 & -0.563 & -0.0673 & $-0.0715^{\star}$ \\
\hline & $(0.350)$ & $(0.345)$ & $(0.0801)$ & $(0.0425)$ \\
\hline \multirow{2}{*}{$\begin{array}{r}\text { BPL_card } \\
\text { holder }\end{array}$} & -0.705 & -0.936 & $0.485^{\star \star}$ & $0.192^{\star}$ \\
\hline & (1.551) & (1.526) & $(0.205)$ & $(0.108)$ \\
\hline \multirow{2}{*}{$\begin{array}{r}A A Y \text { card } \\
\text { holder }\end{array}$} & 0.554 & $1.117^{* *}$ & $0.511^{\star \star *}$ & $0.210^{\star * *}$ \\
\hline & $(0.468)$ & $(0.461)$ & $(0.0976)$ & $(0.0521)$ \\
\hline \multirow{2}{*}{$\begin{array}{r}\text { landholding } \\
\text { size }\end{array}$} & -0.120 & $-0.139^{\star}$ & -0.0106 & -0.00812 \\
\hline & $(0.0753)$ & $(0.0741)$ & $\begin{array}{c}(0.00931 \\
)\end{array}$ & $\begin{array}{c}(0.00510 \\
)\end{array}$ \\
\hline \multirow{3}{*}{$\begin{array}{r}\text { Whether } \\
\text { mukhia \& } \\
\text { dealer from } \\
\text { same caste }\end{array}$} & -0.402 & -0.522 & -0.171 & 0.0257 \\
\hline & & & & \\
\hline & $(0.601)$ & $(0.591)$ & $(0.141)$ & $(0.0737)$ \\
\hline \multirow{2}{*}{$\begin{array}{r}\text { Ever had } \\
\text { conflict with } \\
\text { dealer }\end{array}$} & -0.414 & -0.242 & 0.116 & 0.0274 \\
\hline & $(0.381)$ & $(0.375)$ & $(0.0981)$ & $(0.0527)$ \\
\hline Whether & 0.407 & 0.346 & $0.171^{\star \star}$ & $0.119^{\star \star \star}$ \\
\hline
\end{tabular}




\begin{tabular}{r|cccc}
$\begin{array}{r}\text { dealer from } \\
\text { same caste }\end{array}$ & & & & \\
Constant & $(0.307)$ & $(0.302)$ & $(\mathbf{0 . 0 7 0 4 )}$ & $(\mathbf{0 . 0 3 7 4 )}$ \\
& $4.164^{* * *}$ & $3.374^{* *}$ & $1.460^{* * *}$ & $1.090^{* * *}$ \\
& $(1.361)$ & $(1.339)$ & $(0.348)$ & $(0.181)$ \\
$\begin{array}{r}\text { Observation } \\
S\end{array}$ & 457 & 457 & 837 & 811 \\
$R$-squared & 0.153 & 0.192 & 0.220 & 0.243 \\
& & & &
\end{tabular}

When examining the true gender effect in accessing PDS we need to move beyond a focus on FHH to an in-depth analysis of the pathways for differentiation, and family and community structures that might perpetuate inequalities for women in different social positions. Results in table 3, for instance, show clearly the importance of landholdings in mitigating snatching. We also use non-food expenditure as a proxy for standard of living and a marker of economic strength. Richer households have higher non-food expenditure after controlling for other determinants of snatching.

Given the deeply entrenched caste system in India, especially in a state like Bihar, surprisingly, outcomes for households who share the same caste group as the PDS dealer, that is, homophily with the dealer, does not seem to have a major impact on improving access or greater uptake from the PDS. If there is a status quo in incentive structures and the payoffs to the dealers are small, ${ }^{4}$ homophily does not seem to have an effect. In fact, the potential benefits of favoring one's own caste is outweighed by the possibility of leaking grains to the open market as a dealer. Kumar and Somanathan (2016) confirm that though homophily works in large onetime transfers such as government's flagship housing programme, the Indira Awas Yojana, it does not have the same results for "smaller" and "repeated transfer" systems like PDS for food.

\footnotetext{
${ }^{4}$ Unlike the case of Chhattisgarh where the commission of the PDS dealer was raised manifold and resulted in reduced leakages (Krishnamurthy et al (2014).
} 


\section{Section 4: The workings of power: insights from the qualitative data}

Table 3 reveals a significant effect of holding particular types of cards. In this section, based on our qualitative insights, we discuss the differences between differently positioned women, especially SC women, in getting access to such cards. The nature of odds faced by these women would ultimately determine the level and quality of gender-justice in accessing the PDS.

\subsection{Local power politics}

The regression results (Table 3) point to the existence of significant village level factors affecting access outcomes. One needs to remember therefore that village level heterogeneity, including in gender relations, underscores the need for customized local solutions, if food entitlements have to be gender just.

The interplay of caste, gender and class, alongside local politics and power relations, was clearly illustrated by the case of village A in Patna district. This village is unique as there were de facto two Mukhiyas (headman): one incumbent Mukhiya (upper caste Bhumihar) who had been in this position for many years, and the other a proxy Mukhiya (of lower caste). The second was elected when the position was reserved for an SC candidate ${ }^{5}$. Having served as a bonded labourer in the upper caste Mukhiya's house, he had no real power. His wife and his daughter too were engaged in the service of the Bhumihar (former) Mukhiya's house.

Low caste households then did not draw any benefit from homophily with the Mukhiya, even though the Bhumihars are a minority in the village, the majority being from the $\mathrm{SC}$ and $\mathrm{OBC}$ category. Despite the low numbers, the upper castes continued to wield power, manifested in the way that ration cards were used as a tool to garner votes during the election. An SC woman whose husband is a car driver in Patna

\footnotetext{
${ }^{5}$ The $73^{\text {rd }}$ and $74^{\text {th }}$ Constitutional Amendments, 1992, ensured 33 per cent reservation for women, SCs and STs at all three tiers of local government, from the village panchayat to the district.
} 
(nearby city), was denied the ration card, because, she believes, of her allegiance to the opposing upper caste Bhumihar household, who had contested and lost the Mukhiya election. With no work, she now helps in this household with domestic chores like washing, cleaning, and other menial jobs with a hope that whenever the man of this household wins the Mukhiya election, he will favour her. She complained that while she was denied the card, others, the "landed people" comprising mainly the upper caste Bhumihars have a card.

As the village is divided in two factions, both led by Bhumihars, SC women maintained that the dealer belonging to their caste did not help them. Here, homophily by construction does not seem to matter as local politics and power relations play an overriding role. Any dealer, they allege, to continue in the dealership, must have the "blessings" of the upper caste Mukhiya. And this dealer is no different. They further added that, "Caste and gender of the dealer makes no difference. The Mukhiya rules the dealer. If the Mukhiya wants, even if you do not have a card, you will get the ration. He just needs to direct the dealer. He writes on a piece of paper and you can show that to the dealer, he will not deny you grains". They also alleged that though the dealer does not overtly discriminate against them, during disbursement he is partial to the upper castes and those with social contacts.

Earlier the present dealer's father was the one distributing the grains. The PDS shop was in the lower caste hamlet. But being an alcoholic, he was irregular in distributing the grains. This resulted in fights at the PDS shop, when upper castes, who considered it below their dignity to stand in a line in a lower caste hamlet would break the line and take their share, while the lower castes would be left jostling for theirs. Once, losing patience, the PDS dealer was physically assaulted by the lower castes. The Mukhiya then decided to move the PDS shop near his house and run it under his supervision. Since then, the son of the dealer, who is pursuing higher studies in the city, took over the dealership. He got the dealer license, which was almost cancelled based on villagers' complaints renewed. We were told that the 
Bhumihar (who lost the election) in fact orchestrated the whole episode, instigating the villagers of his faction to file a written complaint. This was to teach the ruling Mukhiya, who was the patron of the dealer, a lesson.

\subsection{Clan (gotiya) matters more than caste}

Village B, also in Patna district, provides an interesting contrast. Unlike the clear dominance of the Bhumihars in village A in determining the outcomes related to the PDS, a single caste group, the Yadavs, populates this village, with a few SC households. While classified as Other Backward Caste (OBC), the Yadavs are relatively well placed economically and politically. Considering the homogeneity of its population, one would expect the PDS to function well. In this case, both the dealer and the Mukhiya belonged to the same Yadav caste. However, the PDS functioning here was the worst of the villages in Patna district. Most respondents, except for a few households of the same clan, said that grains are disbursed for only about 8 months of the year, the rest is siphoned off by the dealer. The quantity and quality were always an issue, and the dealer would charge a higher price. When the women objected, he would retaliate by being abusive towards them, tear and throw away their cards, or if several protested jointly, he would simply close the shop and go away.

Most respondents said that his behaviour was rude (dealer ka nature bahut kharab hai), disrespectful to women, and more so with lower caste women. "If we protest, he calls us names, and says that I am a mad woman" (Janani pagal hai), said one woman respondent. Most of them agreed that all dealers are the same, they are in touch with each other, call each other and set the rate of the grains (higher than the government price). "They cheat us with the quantity by making holes in the rice sacks (Boma maar dete hain), and the excuse they always give is that the sacks come like this, causing wastage during the loading and unloading of the grains". 
While a majority complained about the PDS dealer siphoning of grains, giving less quantity, and of inferior quality, among others, they also alleged that despite being of the same caste, he discriminates by giving preferential treatment to his relatives or the same clan (gotiye). As one woman observed, "It is very crowded at the PDS shop. On top of that, he will make us wait for three to four hours if his clan/gotra people come to collect their ration. One of the dealer's relatives proudly confirmed, "We are the gotiye of the dealer. He ensures that we get the ration. He will call us and give if we do not turn up during the time he is disbursing". Others also noted that apart from his gotiyas, to survive in this dealership, he keeps 'important' people, based on social standing, economic clout, and political connections, happy.

\subsection{Considerations of Status}

In Village C, women from the upper castes noted that, "Women from good families do not go to collect PDS grains, it is the men who go, and women from the lower castes". Yet, how the upper caste women access their PDS grains differed by village. While in village $C$ the upper caste women thought it was below their dignity to go to the PDS shop, in village A, owing to their relatively low economic status, they did not shy away from doing so. Caste, gender and class all work together in this context.

In fact, in village $\mathrm{A}$, one of the upper caste women (economically better off than most of the lower caste households), who was very vocal about her right to the PDS grains, said: "I get the right quantity. However crowded it may be during disbursement, I always choose the good quality rice sack. I pay Rupees 100 which is higher than the quota price but I do not mind". In this case, there was an implicit show of strength when she narrated how in earlier days she was on good terms with the current Mukhiya (of the same caste as hers) and how her son was his active supporter. Interestingly, the upper caste households do not use PDS grains for self-consumption since most have 
access to their self-produced grains. The comparatively well-off households, even if they do not need PDS as much, make it a point to collect the grains since they have a ration card and believe it to be their right to get it (entitlement fetching). The PDS grains are either sold off (the money of which is in control of the women of the household who spend it on either jewellery or other needs), fed to the cattle or given away to the agricultural labourers who work on their fields in lieu of wage.

There are instances as well where despite being of upper caste, being single, young and of low economic status, the experience of access is quite different for women. A woman in her late 20s (upper caste widow) with a 10-year-old son has never gone to the PDS shop. She sustains herself mostly by taking up small tailoring jobs that her neighbours get her. Being young and a widow, she feels vulnerable to villagers discussing her movement and interpreting her going out as transgression. This potential social stigma constrains her from accessing PDS grains. She sends her 10year-old son to fetch it. The position of women in the social and institutional milieu has a bearing on the difficulties they encounter in accessing their entitlements. In this case, despite being young and capable, the fear of social stigma restricted her access.

Though we have broadly argued that homophily does not work, the social identity of the dealer worked to their advantage for some of the upper caste women. As explained by one of them, "He (dealer) cannot misbehave with us. He has the reverence considering that we are from the upper caste (Bhumihar caste specifically). The dealer takes extra care when we go to the PDS shop. He will not make us wait. He will let us choose the sack of rice that we want to pick". Moreover, the location of the PDS shop too mattered. In the village A, the PDS shop was located near the Mukhiya's house (upper caste).

\subsection{Poor delivery and the absence of redressal}


While discussing the dealer's son in village $A$, the women noted that though his behaviour is good, better than his father's, he is entirely controlled by the Mukhiya. They felt that the Mukhiya in connivance with the dealer is interested in making profits. "He gives more to the upper castes, he gives them whatever they ask for. If we (women) protest, he says either take this or nothing at all", said some of them. The usual complaints related to quantity, quality and measurement issues, though they were content with his regularity. They have to wait longer in line, for less quantity or inferior quality rice at a higher price.

The women knew that as the Mukhiya is well connected, nothing will change even if they complained. Most were scared to complain because the Mukhiya would threaten to strike off their names from the list of ration cardholders. One of them recounted a case where, when she complained, the next she knew her ration was withdrawn. Most of the SC women observed, "if the dealer is of the same caste, they are more your enemy, as they exploit you even more. A Bhumihar dealer, however, will be no different, and the worst is we cannot say anything to the upper castes; at least with a lower caste we can fight". With such entrenched power relations, the prospects for gender justice are bleak.

What emerges is that the dealers let the upper castes choose the grains, give them an extra sack of grains if required, while amongst the lower castes, they favour those they view as potential trouble makers. Further, when the PDS shop is too crowded, the upper castes get priority and the SCs made to wait. The PDS shop remains open only for a day, and the date of distribution is not fixed. "We come to know of it by word of mouth or when we see people going to the shop. During that time whoever comes gets the grain, if you miss that, you do not get it later", said an SC woman. Since the PDS shop is now located near the Mukhiya's house, SC women restrain themselves from fighting there. When they leave the premises, however, they are vocal in abusing the dealer, some of them added in jest. 


\section{Conclusions:}

In this paper, we have focused on the experiences with the PDS in Bihar and examined the nature of food entitlements accessible to differently positioned people, in particular women. Our objective was to capture the nuances of gender justice/injustice in accessing PDS grains, by exploring both the quality of the entitlement and the nature of treatment meted out to the entitlement-holders.

Since so much is invested in the ration cards of different forms, local power and political economy become very important in determining access through controlling these cards. Despite being a universal right, control over ration cards becomes a strong instrument for discriminating against women, the lower castes and the economically less powerful. While overt discrimination is less visible after the passage of the NFSA, quality is one instrument that can be more easily used for differentiation because of its intangibility and imperfect observability.

Though we found limited evidence on direct entitlement snatching in terms of the quantity or price of grains, the qualitative data highlighted the locational heterogeneity in gendered access as well as the differentiation based on group identity. While caste is an important marker of social identity in India, some of the expected benefits of homophily do not exist. In fact, with their newfound power, the lower caste dealers end up being more aggressive in denying rights to their own caste groups. The quality of services is markedly inferior for the groups in focus here, revealing several latent methods through which discrimination is practiced, including lack of information, mixing of inferior grains, longer waiting time and even verbal abuse. These mechanisms impinge negatively on gender justice by not just devaluing women's work and time, but also compromising their dignity as rights-holders. 
Despite equal and universal entitlements, achieving gender justice in access to food through state transfers will require further shifts in power relations, in name but also in practice. It would involve challenging, renegotiating and transforming unequal social relationships, and institutional structures and norms that perpetuate such inequalities. Apart from improving access to information, monitoring and redressal systems need to be strengthened in order to overcome the near-total control of the local political elite, often the better-off, landowners and upper castes. While we have focused on community level parameters in this paper in discussing the delivery of entitlements by the state, we are likely to encounter similar issues of power in the realm of food production and absorption, albeit at different scales, from the global and national economy to the household.

Acknowledgements:

We would like to thank IFPRI, New Delhi Office, especially Devesh Roy, for comments on an earlier draft and making accessible the survey data used in this paper. We thank the anonymous reviewers for their useful comments.

\section{Appendix 1:}

Effective price

By law consumers have mandated prices. The survey data commonly shows price magnification where households are charged a little more than the legitimate price. The amount by which the beneficiaries have price magnification nominally is often identical across households. However, in quantity terms the extent of entitlement snatching varies quite significantly. Hence, we look at the price realization by developing the concept of effective price as defined below:

$$
E P_{i}=\frac{\text { Entitlement }_{i}}{\text { Accrual }_{i}} * P_{i}
$$

Where $E P_{i}$ is the effective price faced by household $i$ Entitlement $_{i}$ and Accrual $_{i}$ are the mandated and accrued quantities for household $i$. With this definition greater is 
the accrual relative to entitlement, lower is the effective price. Hence, even if two consumers face same price, effectively the households with greater degree of compromise of the entitlement effectively faces higher prices. This creates variation in the effective prices across beneficiaries.

\section{References:}

Agarwal, B. (1997). Bargaining and Gender relations: Within and Beyond the Household. Feminist Economics 3 (1): 1-51.

Agarwal, B. (2012). Food security, productivity, and gender inequality. Institute of Economic Growth. IEG Working Paper No. 320. New Delhi.

BRIDGE InBrief (2015). Overview report. Towards Gender-just and Food and Nutrition Security. Institute of Development Studies.

Birner, R and Anderson, J.R. (2007). How to make agricultural extension demanddriven?: The case of India's agricultural extension policy. IFPRI Discussion Paper 00729. Washington D.C. IFPRI.

Deaton, A and Dreze, J. (2002). Poverty and inequality in India: a re-examination. Working Paper 184. Princeton University.

Deshpande, A. (2002). Assets versus Autonomy: The Changing Face of the GenderCaste Overlap in India." Feminist Economics 8, no. 2:19-35.

Deshpande, A. (2007). Overlapping Identities under Liberalization: Gender and Caste in India. Economic Development and cultural change. University of Chicago.

Dreze, J. and Khera, R. (2013). Rural Poverty and the Public Distribution System. Center for Development Economics. Working Paper 235. September. Delhi School of Economics. 
Food and Agricultural Organization (FAO). (1996). Rome declaration on world food security. Rome: FAO.

Food and Agricultural Organization (FAO). (2011) The state of food and agriculture 2010-2011. Women in agriculture: closing the gender gap for development. Rome: FAO, available at: http://www.fao.org/docrep/013/i2050e/i2050e00.htm

Fraser, N. (1989) Unruly Practices. Cambridge: Polity Press.

IFPRI. (2017). The Global Hunger Index 2017: the inequalities of hunger. International Food Policy Research Institute. Washington D.C.

Kabeer, N. (1994). Reversed Realities: Gender Hierarchies in Development Thought. London: Verso Publications.

Krishnamurthy, P., Pathania, V and Tandon, S. (2014). Public Distribution System Reforms and

Consumption in Chhattisgarh: A Comparative Empirical Analysis. Economic \& Political Weekly, 49(8): 74-81.

Kumar, H and Somanathan, R. (2016). Caste connections and government transfers: The Mahadalits of Bihar. Working Paper No. 270. ISSN No. 2454 - 1427. Centre for Development Economics. Delhi School of Economics. Delhi.

Prakash, A. (2010). Dalit entrepreneurs in middle India. In: Harriss-White, B and J. Heyer (eds.) The comparative political economy of development: Africa and South Asia. London. Routledge.

Rao, N, (2008) "Good women do not inherit Land": Politics of Land and Gender in India. Social Science Press and Orient Blackswan, New Delhi.

Rao, N (2014) Caste, Kinship and Life-course: Rethinking Women's Work and Agency in Rural South India. Feminist Economics, 20(4): 78-102.

Ribot, J., Peluso, N. L. (2003) .A Theory of Access. Rural Sociology. 68(2):153-181.

Sen, A. K. (1981). Poverty and Famines: An essay on entitlement and deprivation. Oxford. Oxford University Press.

Sen, A. K. (1999). Development as Freedom. Oxford. Oxford University Press.

Sen, A. K. (2009). The idea of justice. London. Penguin Books. 
Swaminathan, H., Suchitra, J.Y and Lahoti, R. (2011). Karnataka Household Asset Survey: Measuring the gender asset gap. Bangalore. Indian Institute of Management. Bangalore.

The National Food Security Act. (2013). Ministry of Law and Justice (Legislative Department). Government of India. New Delhi.

Thorat, S and Sadana, N. (2009). Discrimination and children's nutritional status in India. IDS Bulletin 40: 25-29.

Thorat, S and Lee, J. (2006). Caste Discrimination and Food Security Programmes. Economic and Political Weekly. September 24. 